\title{
Impact Of Tariff On Income: Cross Country Analysis
}

\author{
Sidra Imran Amin \\ Ambreen Fatima ${ }^{2}$
}

\begin{abstract}
The purpose of the study is to assess the significance of import tariff on the economic growth of ten countries divided into two groups; developing and developed economies. The developed countries included in the sample are Australia, Japan, Canada, Turkey and United States. The developing group of countries consists of Pakistan, Sri Lanka, India, Bangladesh and Thailand. The time period taken span from 1998 till 2015.The cross-country analysis included in the study ranges from the application of OLS regression methods to country wise, unit root test and long run analysis. In addition, Panel Unit Root and Panel Cointegration Tests are also performed to enhance the analysis. The test results of Unit Root Test show that the series are non-stationary at level and on taking first difference these becomes stationary. After we established that the series are integrated of order 1 we proceeded with the Johansen test of Cointegration which established the long run associations among the variables. The Panel Cointegration (Larsson et al. 2001) technique is used to establish the long run association in a panel framework. The findings show long run associations among the variables. It is however reviewed that the policy variable import tariff cannot be used standalone to bring prosperity for the country specially in developing countries. The country needs support of infrastructure enhancement, technological advancement and education in order to fully reap the benefits of protection provided to the industries.
\end{abstract}

JEL Classification: $F 14,011$

Keywords: OLS Regression, Panel (IPS), Johansen Cointegration, Panel Cointegration

\section{INTRODUCTION}

The ratio between the world trade and the world GDP has been a subject of attention in the recent literature which is also a summary statistic for globalization. According to the International Monetary Fund statistics a sharp decline is observed in both the volume and the value of the goods and services traded. IMF states that the volume has lessened and the value in terms of dollar trade has almost collapsed during the latter part of 2014 and a $10 \%$ fall is seen regarding its value mainly due to the sharp decline in imports and a drop in the oil prices and appreciated dollar value. The volume of trade has experienced a very low growth rate amounting to half the average of what it was during the previous years.

The import growth is observed to have slowed down for both developed economies and the developing economies. However, the developed economies experienced the downturn first mainly due to the debt crises in the European zone. The slow growth of trade has now increased in pace and the driving factor is the similar weak conditions in the developing countries which are also exporting.

To understand the reasons behind these changes, the economists have studied the relationship between import and growth along with the relative shift in the prices. The growth factors

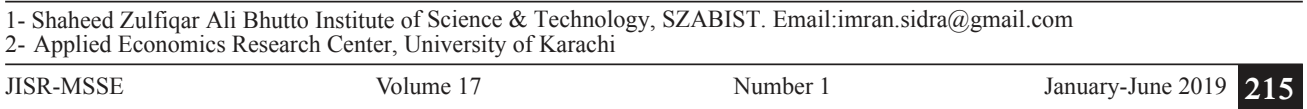


studied are consumption and investment, government expenditure and the export and import volume. IMF based on its comparative study concluded that more than $75 \%$ of the slower growth is due to the shift of economic activity from highly import intensive to less import intensive and the ripple effect observed across the markets.

The factors responsible for the slowdown in the world trade can be explained by several possible reasons but in this research tariffs and trade policies are the major concern.

Trade policy is one of the major aspects of the wider development process of any economy. The link between trade liberalization policies and the economic growth has been widely studied and the conclusions are ambiguous where in some cases the effect of the relationship is positive and in some cases the relationship is negative. This study is aimed to carry out this relationship and taken to a step further by analyzing how the impact is felt for different countries with varying income levels. The motivation in carrying out the study results from the fact that similar trade policies will have different impact on the economies having different income groups. If the relation is clarified and made unambiguous than the research can be taken further to micro level of data analysis. It is assumed that the global economic integration should help poor since the comparative advantage exists with poor countries on producing goods with unskilled labour. The rules and regulations affecting the international trade and trade policy is becoming increasingly complex and multifaceted. It becomes very important to understand the uses and implications of these policies in order to implement better strategies.

Tariff is the most usual type of obstacle to trade. The basic functions of tariffs include, to bring about revenue, as a factor of protection for domestic industries. Tariff income is as source of provision of income for the government. However, the case is slightly different for developed countries, because these countries have a proper and organised system of tax codes. Japan being a developed country generates about a trillion yen in the form of tariff revenue. When tariff is used as a protection by developing countries, competitive import is being decremented. Tariff quotas are a way to bring a balance between the protection of industries domestically and to gain access internationally. While given protection to the domestic industries, the economy of the country bears the cost of a reduced welfare of the economy. Tariffs are classified, according to the classification numbers assigned to different good and then they have their corresponding rates.

The tariff levels are bound to move in a cycle in collaboration with a business cycle. When there are periods of boom it is observed that the levels of tariff are at a lower level. As soon as the phase of business cycle enters a recession the tariff is raised again. If there is import restrictions on one set of goods, then a subsequent reduction is observed in the other set of goods. When the business cycle is at its peak, the rigidity of downward wage results in unemployment in some of the sectors. In case of a trough, import tariff restrictions leads to the increase in the employment domestically. Thus, the impact of tariff is observed in the overall economy of the country as well. It is argued that benefits of protection are not uniformly distributed amongst the regions or industries in import. When the economic conditions are taking a downturn, the regions who are rated as the old regions will tend to increase the tariff. On the other hand when a peak is observed the chance is greatest for the regions of free traders to win.

Thus, the distributive effect of tariff imposition on the economic growth has vastly remained

216 January-June $2019 \quad$ Volume $17 \quad$ Number $1 \quad$ JISR-MSSE


as a subject of study. It is also important to strike a better balance between the interest of the developed world and the developing world. The poor developing world makes products and the developed nations are usually unwelcoming towards it specially the agricultural, and textile products. If the developed countries protect their own economies, they deny the developing world access. To avoid such skewness, the organisation such as WTO keeps checks and balances. This depict the importance of the relationship between tariff and economy.

\section{Study Objectives}

The research objectives prepared for this study are as follows

1. To assess the significance level of how import tariff impacts the economic growth/income of a country.

2. To assess the long run relationship between economic growth/income of a country and import tariff.

\section{Significance of the Study}

The goal of the research is to assess the effects of how trade liberalization policies and particularly the tariff tool affects the economic growth of different economies.

Since serious ambiguity exists between the relationship between trade policies and their impact on the economic growth therefore further research on this important subject is necessary. Furthermore, this study examines the impact on the economies with varying income levels, i.e. the impact is studied on developing economies such as Pakistan India, Bangladesh, Sri Lanka and Thailand and developed economies such as US, Australia, China, Turkey and Japan.

It is important to identify the difference between the developing countries and the developed countries because the developing countries are already struggling for their macroeconomic stability, which can lead to the reduction in the revenue for such countries if the industries are not protected.

\section{LITERATURE REVIEW}

The literature evidence depicts the importance of use of simple linear models with which the relationship between tariff and income is investigated in a cross-country framework.

John Ballingl, 2010 conducted a study under the New Zealand Institute of Economic Research and used the CGE model to analyse the impact that the removal of all tariff restrictions has on the consumer welfare level and the level of allocative efficiency gains. The results depict that the consumer will fall to be in the worse situation if the existing low level of tariff are taken away, however the allocative efficiency will deliver gains. The results of the study are contrary to the existing notion, and the economists believe that further reduction of tariff will result in further gains. The study emphasized on the point that the terms of trade has a very important role in evaluating the gains of the policy implications, specifically when the policy matters are already in the lower lying range. 
Siddiqui et al., 1999 studies the impact of reduction of industrialized goods across households, It is observed that for lower income groups the impact is higher. When the tariff is reduced it increases the gap between the rich and the poor. As a conclusion this paper observes that the reduction in tariff rates is worsening the income distribution of the economy as a whole in urban and rural areas leading to a decline in investment as well.

Kowalski, 2004 discussed the issues that are associated with the estimation of revenue impacts for a small sample of developing countries. The impact is studied for cross country where different tariff policies are implemented. The paper also discusses tax replacement policies which are efficient. The results of his study indicate considerable amount of cross-country differences in trade, welfare and revenue impact. Countries with higher tariff experiences deeper percentage revenue loss and deeper gains in welfare.

Sachs \& Warner, 1995 in the research paper empirically investigated the relationship and supported the view that trade liberalization leads to more rapid growth of the economy resulting in poverty reduction. Even though several studies have identified positive relation between trade policy openness and growth, the direction of the relationship remains unclear.

Paulino 2012 in one of the working papers studied the effect of trade, income distribution and poverty in developing countries. He was of the view that trade liberalization improves aggregate welfare, but the gains are small and unequally distributed. The effects of welfare are measured through price changes, with the focus on how the relative demand for domestic factors of production and in particular the demand for skilled relative to unskilled labor is affected. Poverty origin sources are also great such as skills, infrastructure policies etc. and it remains one of the constraints of the production function.

\section{ECONOMETRIC METHODOLOGY, DATA, AND VARIABLES}

The variables undertaken for study are widely accepted in the literature as the main determinant which capture the growth of the country. The data will comprise of heterogeneous group of countries with varying income levels, sizes, degree of trade openness etc.

A thorough analysis of the literature review suggests that there is a relationship between import tariff, a policy variable of trade liberalization and economic growth. The relationship vastly depicts varying behaviors across countries with differing levels of developments. As stated earlier the undertaken study examines the relationship between import tariff and economic development for two groups of countries empirically.

\section{Procedure}

- As a first step data of different countries is gathered from reliable data sources. Due to the non-availability of the data of import tariff the time span is restricted to 17 years only. The time period chosen for the study span from 1998 to 2015, thus making it a sample of 17 years for each country.

- Data Processing is done through application of statistical and econometric models. Since the dataset consists of a number of countries, therefore first the estimation is performed for each country and then a combined effect of all the countries is observed using methods of panel data investigation.

218 January-June $2019 \quad$ Volume $17 \quad$ Number 12 JISR-MSSE 


\section{Data and Source}

Data is collected for this research from multiple sources, such as Work Bank Development Indicator (WDI) and statistics of United Nations Conference on Trade and Development (UNCTAD). The countries analyzed are grouped into two, developing and developed. Developed countries are Australia, Canada, Turkey, United States, and Japan, whereas developing countries are Pakistan, India, Bangladesh Sri Lanka, and Thailand. The time period taken for these 10 countries is from 1998 to 2015 . The data taken is annual in nature to better accommodate the impact of macroeconomic variable undertaken which helps in yielding smaller degrees of freedom and better approximations of the relationships between variables.

The variables undertaken are gross domestic product, import tariff, trade and population; each one is defined below.

\section{Variable Selection and Transformation}

The selection of the variables is made with full support of literature review. There is sound evidence that the variables are found to have an impact on the dependent variable which is economic growth. Brief description of the variables is as under,

- Average Tariff: Tariff is the tax which is imposed on the imported goods and services. The value of tariff is taken in percentages.

- Gross Domestic Product: Gross Domestic Product (GDP) is taken as a proxy for economic growth. It is taken as per capita, which is the net effect of income, taken by dividing the total income by the population.

- Trade Openness: Trade openness is basically the exchange of goods and services between one economy to another. The measure is taken as Millions of US Dollars taken as a percentage of GDP

- Population: The annual growth rate of population is taken for each country

Following Hypothesis have been developed to answer the research questions.

HANull: Import tariff does not significantly impact the economic growth/income of a country.

HAAlternate: Import tariff significantly impacts the economic growth/income of a country.

HвNull: A long run relationship does not exist between the economic growth/income of a country and import tariff.

HвAlternate: A long run relationship exists between economic growth/income of a country and import tariff.

\section{DATA ANALYSIS AND FINDINGS}

\section{Econometric Model}

To investigate the relationship between import tariff and income, represented by the proxy of GDP per capita we start with a simple model. The investigation proceeds by first formulating the general form of the equation defined as;

$$
Y_{t}=f\left(P_{t}, I_{t}, T_{t}\right)
$$


where,
$\mathrm{Y}_{\mathrm{t}}=$ Economic Growth (GDP per capita)
$\mathrm{P}_{\mathrm{t}}=$ Population of the country
$\mathrm{T}_{\mathrm{t}}=$ Trade (as a percentage of GDP)
It $=$ Average Import Tariff

The basic equation of regression derived from the above general framework is as follows;

$$
\mathrm{Y}_{\mathrm{it}}=\alpha+\alpha_{1} \mathrm{P}_{\mathrm{it}}+\alpha_{2} \mathrm{~T}_{\mathrm{it}}+\alpha_{3} \mathrm{I}_{\mathrm{it}}+\varepsilon_{\mathrm{it}} .
$$

Here $\alpha_{1}, \alpha_{2}, \alpha_{3}$ are the elasticities and estimated parameters and $\varepsilon t$ is the error term and $\alpha_{0}$ is the constant. The cross-section data attribute is represented by $i$ and the time series element is depicted by the subscript $t$. The analysis proceeds towards the regression estimations in the next section.

\section{Regression Analysis}

There are four approaches which an analyst can use to examine the multilevel data of countries namely separate models for each country, pooled OLS regression, country fixed effect models and country random effect models. In this empirical study, we have analyzed the separate country wise estimation, Pooled OLS estimation to analyze the issue. The research can be further enhanced by incorporating the heterogeneity element of the data and performing fixed effect or random effect OLS estimations based on Hausman test if the number of observations is increased.

\section{Country Wise}

As a first step of regression analysis, an OLS estimation technique is applied to estimate the above equation for each country avoiding the time series properties. The country effect in this type of regression the individual effect of the country is absorbed and is independent of the intercept. The coefficients of the regression analysis are different across each country and show the individual effects.

Table 1: Country Wise OLS Regression

\begin{tabular}{l|l|l|l}
\hline & Population & Trade & Import Tariff \\
\hline Developed & & & \\
\hline Australia & $-0.211(-0.34)$ & $-0.174(-1.72)$ & $0.46(2.29)$ \\
\hline Canada & $-7.32(-2.44)$ & $0.27(4.46)$ & $-2.29(-4.46)$ \\
\hline Japan & $3.27(0.46)$ & $0.052(0.32)$ & $-1.55(-0.41)$ \\
\hline Turkey & $15.93(1.78)$ & $-0.727(-1.90)$ & $-7.288(-2.65)$ \\
\hline United States & $12.207(1.39)$ & $-0.032(-0.16)$ & $-2.457(-0.73)$ \\
\hline Developing & & & \\
\hline Bangladesh & $0.088(0.05)$ & $0.0564(1.30)$ & $-0.059(-0.42)$ \\
\hline Thailand & $4.84(1.61)$ & $-0.0099(-0.07)$ & $0.2918(-1.82)$ \\
\hline India & $2.10(0.25)$ & $-0.12(-0.70)$ & $-2.30(-1.21)$ \\
\hline Pakistan & $-11.99(-1.36)$ & $-0.097(-0.02)$ & $0.095(0.78)$ \\
\hline Sri Lanka & $4.17(0.38)$ & $-0.002(-0.46)$ & $1.22(1.35)$ \\
\hline Note: Thet statistics & & &
\end{tabular}

Note: The t statistics is mentioned in the brackets 
It is evident from the table that average tariff rate impact economic development significantly and negatively to Canada, Turkey and Thailand. The impact is positive and significant only for Australia. In addition, trade openness is positively impacting the GDP in case of Canada only.

\section{Pooled OLS}

In this step, we simply pool the data of all the observations of the countries whose summary is presented here. Overall a significant relationship appears when the data is pooled and for the undertaken countries, ignoring the heterogeneity bias and the omitted variable bias, we can conclude that tariff does have an impact on the dependent variable GDP.

Table 2: : Pooled OLS Statistics

\begin{tabular}{l|l|l|l}
\hline & Population & Trade & Import tariff \\
\hline Pooled data & $1.35(2.97)$ & $0.14(1.84)$ & $1.18(1.64)$ \\
\hline
\end{tabular}

Note: The $t$ statistics are mentioned in the brackets

It is evident from the table that all the variables population, trade openness and tariff rate on average are enhancing the economic development.

\section{Exploring the Time Series Properties}

\section{Data Stationarity Assessment}

Econometric data is said to be stationary if there exists no unit root. The mean and variance of data are not dependent on time. Data reverts to its mean quickly if the data is stationary. Data stationarity is one of the most important steps in analyzing time series because, in a time series, which is stationary the shocks i.e. any change in the behavior of the variable usually fades away or becomes lesser with the increase in time. Also, non-stationary data leads to spurious regression results and the assumptions of the model will not be valid. Augmented Dickey Fuller test is used for the data stationarity assessment. This assumes constant variance and the error terms which are independent.

\section{ADF Unit Root test}

As a first step before proceeding to panel unit root analysis, individual ADF test is applied to each series of data incorporating the individual tests of the time series data

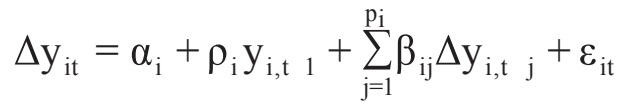

Where; $\mathrm{i}=1, \ldots, N$ and $t=1, \ldots, T$

Thus, a separate test statistic is obtained for each cross section of the data. It tells the order of integration.

\section{Unit Root in Panel Data IPS Test}

In order to determine whether there exists cointegration in panel data, we first need to find out the existence of unit roots. For this analysis, Im, Pearson And Shin (IPS) unit root test is selected which is based on the Augmented Dickey Fuller procedure. The test inculcates the information of time along with the cross-section dimension. This test is selected for application because of its superior power to assess long run relationships in panel data.

\begin{tabular}{llll}
\hline JISR-MSSE & Volume 17 & Number 1 & January-June 2019 221
\end{tabular}


IPS uses the results of the unit root tests done in the previous section. It is based on the Augmented Dickey Fuller test, and is merely the average taken of the individual unit test runs represented by,

$$
\overline{\mathrm{t}}_{\mathrm{NT}}=\frac{1}{\mathrm{~N}} \sum_{\mathrm{i}=1}^{\mathrm{N}} \mathrm{t}_{\mathrm{iT}}\left(\mathrm{p}_{\mathrm{i}} \beta_{\mathrm{i}}\right)
$$

The statistic of $\mathrm{t}$ bar is standardized, and the values of $\mathrm{N}$ and $\mathrm{T}$ converges to infinity in a sequential manner.

As $\mathrm{N}$ moves to infinity, applying the Lindeberg-Levy central limit theorem;

$$
t_{I P S}=\frac{\sqrt{N}\left(\bar{t}-E\left[t_{i T} / \rho_{i}=1\right)\right.}{\sqrt{\operatorname{Var}\left[t_{i T} / \rho_{i=1}\right]}} \Rightarrow N(0,1)
$$

IPS computes the values of $\mathrm{E}[\mathrm{tiT} / \mathrm{Qi}=1]$ and $\operatorname{Var}[\mathrm{tiT} / \mathrm{Qi}=1]$ via simulations, keeping in view different values of $\mathrm{T}$ and $\mathrm{Q}$ \is. It is observed that IPS test show better results when $\mathrm{N}$ and $\mathrm{T}$ are small.

The following table depicts the units root tests of the variables of all the countries along with the panel IPS test statistics. The null hypothesis states that there exists unit root which means the data is nonstationary and the alternative hypothesis is that the data is stationary. Results indicate the presence of unit root at level and the absence of unit root at first difference i.e. the data is stationary. The results are tested for both drift and trend values and the results are found to be consistent in both categories. Since the data aligns with the conditions of cointegration tests, we can now proceed to the panel cointegration assessment.

Table 3: Panel Data IPS Test

\begin{tabular}{l|l|l|l|c}
\hline & \multicolumn{2}{|c|}{ Level } & \multicolumn{2}{c}{ First Difference } \\
\hline Panel ADF & Intercept & Trend & Intercept & Trend \\
\hline GDP & 1.73 & 1.77 & 5.364 & 5.248 \\
\hline Population & 1.20 & 1.34 & 4.015 & 3.951 \\
\hline Trade & 1.25 & 1.75 & 4.127 & 4.213 \\
\hline Import Tariff & 1.39 & 1.52 & 3.716 & 4.574 \\
\hline & & & & \\
\hline Panel Unit Root test t IPS statistic & & & & \\
\hline GDP & 0.700 & -1.346 & 12.144 & 9.859 \\
\hline Population & -1.019 & -2.817 & 7.900 & 5.708 \\
\hline Trade & -0.873 & -1.422 & 8.253 & 6.544 \\
\hline Import Tariff & -0.422 & -2.180 & 6.961 & 7.701 \\
\hline
\end{tabular}

\section{Assessment of Long Run Relationship}

Trade Liberalization impacts the performance of economies differently in the short run and in the long run. After establishment of the fact that the series is non-stationary at level and stationary at first difference, the long run relationship is estimated by using the Johansen and Jusellius (1990) cointegration method (J J Cointegration test). This test is carried out for each country individually and results are summarized in the table. The trace statistic in each case is 
examined to evaluate the null hypothesis against the alternate hypothesis. The ranks indicate the number of cointegration equations;

If the trace statistic is less than the critical value, we accept the null hypothesis and reject the alternate hypothesis, If the null at $\mathrm{R}=0$ is rejected, then we move on to find the rank which is the number of cointegrating equation.

Table 4: Long Run Relationship Results

\begin{tabular}{|c|c|c|}
\hline \multicolumn{3}{|c|}{ Developed Countries } \\
\hline Name & Johansen Cointegration Test & Impact of Tariff on GDP \\
\hline Australia & $\begin{array}{l}\text { The trace statistic is less than the } \\
\text { critical value when the } r=0 \text {. This } \\
\text { implies that the variables show no } \\
\text { cointegration in the long run. }\end{array}$ & Positive \\
\hline Canada & $\begin{array}{l}\text { The null hypothesis of } r=1 \text { i.e. there } \\
\text { is one cointegrating equation is } \\
\text { accepted since the trace statistic is } \\
\text { less than the critical value. This leads } \\
\text { us to the conclusion that these } \\
\text { variables in Canada are showing } \\
\text { long-run equilibrium }\end{array}$ & Negative \\
\hline Japan & $\begin{array}{l}\text { At } \mathrm{R}=2 \text {, the trace statistic becomes } \\
\text { greater than the critical value. Thus, } \\
\text { concluding that the variables in } \\
\text { Japan are showing the relationship in } \\
\text { the long run, and implying that they } \\
\text { converge themselves to equilibrium. }\end{array}$ & Negative \\
\hline Turkey & $\begin{array}{l}\text { The null hypothesis of } \mathrm{R}=1 \text { i.e. there } \\
\text { is one cointegrating equation is } \\
\text { accepted since the trace statistic is } \\
\text { less than the critical value. This leads } \\
\text { us to the conclusion that these } \\
\text { variables in Turkey are showing } \\
\text { long-run equilibrium. }\end{array}$ & Negative \\
\hline \multirow[t]{2}{*}{ United States } & $\begin{array}{l}\text { Results reveal the existence of the } \\
\text { cointegration in the long run since } \\
\text { the test statistics becomes less than } \\
\text { the critical value when } \mathrm{R}=1 \text { i.e. the } \\
\text { null, in this case, is accepted. } \\
\text { Therefore, the variables can move } \\
\text { together in the long run. }\end{array}$ & Negative \\
\hline & Developed Countries & \\
\hline Name & Johansen Cointegration Test & Impact of Tariff on GDP \\
\hline Bangladesh & $\begin{array}{l}\text { On examining } r=2 \text { we find that the } \\
\text { trace statistic is less than the critical }\end{array}$ & Negative \\
\hline
\end{tabular}




\begin{tabular}{|c|c|c|}
\hline & $\begin{array}{l}\text { value hence we accept null here that } \\
\text { there exist } 2 \text { cointegrating equations. }\end{array}$ & \\
\hline Thailand & $\begin{array}{l}\text { On examining } r=4 \text {, we find that the } \\
\text { trace statistic is less than the critical } \\
\text { value hence we accept null here that } \\
\text { there exist } 4 \text { cointegrating equations. }\end{array}$ & Negative \\
\hline India & $\begin{array}{l}\text { The null hypothesis of } r=1 \text { i.e. there } \\
\text { is one cointegrating equation is } \\
\text { accepted since the trace statistic is } \\
\text { less than the critical value. This leads } \\
\text { us to the conclusion that these } \\
\text { variables in India are showing } \\
\text { long-run equilibrium. }\end{array}$ & Positive \\
\hline Pakistan & $\begin{array}{l}\text { The null hypothesis is accepted at } \\
\mathrm{r}=4 \text {, where the trace statistic is less } \\
\text { than the critical value hence the } \\
\text { alternate of the absence of } \\
\text { cointegration is rejected at this level. } \\
\text { Thus, the variables in Pakistan have } \\
\text { a long run relationship between } \\
\text { them. }\end{array}$ & Positive \\
\hline Sri Lanka & $\begin{array}{l}\text { At } r=2 \text { the trace statistic is less than } \\
\text { the critical value implying that there } \\
\text { exists a long-run relationship } \\
\text { between the variables of GDP, } \\
\text { import tariff, trade, and population. }\end{array}$ & Positive \\
\hline
\end{tabular}

\section{Panel Cointegration}

Based on the results of Johansen test for cointegration, a stability is evident among the variables included in our sample analysis and import tariff does impact the economic growth of a country in the long run.

As we have already discussed the results of the IPS test of unit root, at this stage a panel cointegration test can be applied to assess the overall stability of the variables in the long run. The result is stated in the table below which are based upon the Larsson et al, (2001) Likelihood based (LR) panel test of cointegration. According to the test, the null hypothesis states that there exists no cointegration among the variables and the alternative hypothesis states that there exists cointegration among the variables. In case the null hypothesis is rejected, the implications is that average value of the test statistics of the individual countries in the panel, lies at a farther distance from the mean $\mu$, meaning that there exists no cointegration amongst the variables. The Panel Rank test is a one-sided test with the following hypothesis;

$\mathrm{H}_{0}: \operatorname{rank}\left(\prod_{\mathrm{i}}\right)=\mathrm{r}_{\mathrm{i}}<\mathrm{r}$ for all $\mathrm{i}$,

if $Z_{\overline{L R}}(H(r) / \bar{H}(P))>Z_{1-\alpha}$ the null hypothesis is rejected 
The panel results table is as follows

Table 5: Panel Cointegration Results

\begin{tabular}{c|c}
\hline Panel Cointegration & Likelihood Ratio \\
\hline $\mathrm{R}=0$ & 80.413413 \\
\hline $\mathrm{R}<=1$ & 58.80131 \\
\hline $\mathrm{R}<=2$ & 44.63956 \\
\hline $\mathrm{R}<=3$ & 36.35157 \\
\hline $\mathrm{R}<=4$ & 32.522376 \\
\hline $\mathrm{R}<=5$ & 31.497546 \\
\hline
\end{tabular}

Note: $*$ represent significant at $5 \%$. Critical Value for $5 \%$ and above is 1.645

The results are found to be statistically significant at $5 \%$ significant level.

\section{Key Findings}

In the study, we empirically defined the relation between average import tariff and economic growth and the degree of cointegration by dividing the countries into two groups of developed and developing countries. For the illumination of trade liberalization, several key variables are utilized which are average import tariff, GDP per capita as a proxy for economic growth, trade, and population. Seemingly the tariff data is reducing with years with a significant percentage in the developing countries and a less significant impact in the developed countries thus depicting a pattern of tariff reduction. Imports of various goods and technologies help in increasing productivity of any economy It is observed that with the tariff reductions and the liberalization of trade, the developing countries are able to access the markets of developed countries adequately, thus moving to a more open economy with export credentials including raw materials and the nations primary product.

A simple econometric model was formulated to analyze the impact of tariff on income of a country. For this purpose, cross country and panel analysis is done. Regression Estimations reveal that average import tariff rate has significant and negative impact on economic growth of Canada, Turkey and Thailand. In case of Australia its impact is positive and significant as well. In case of Canada, trade openness also has a positive impact on the GDP. The results obtained empirically through the unit root test and the Panel IPS test specify that the level of stationarity in I(1). The cointegration test was also carried out at both levels of cross country and panel. These tests were based on the Johansen and Jusilleus methods of cointegration and the Larson et al. panel cointegration test was done. All the developed and developing nation show a relationship in the long run which is stable. Thus, the alternate hypothesis A and B is accepted.

\section{CONCLUSION AND RECOMMENDATIONS}

Does tariff impact the economic growth of countries? According to the vast assessment of different countries with varying levels of developments, it can be believed that the answer is affirmative. The positive long run relationships among import tariff and economic growth confirm this, although the causality remains unclear whether the trade policies and their variations affect economic growth or the economic growth impacts trade. Also, the economic growth can be affected through various channels of trade, import tariff being one of them

\begin{tabular}{llll}
\hline JISR-MSSE & Volume 17 & Number 1 & January-June 2019225
\end{tabular}


which is a policy variable of trade liberalization. This area can be explored further in the research to accommodate unbiased estimators and inconsistent results. For this purpose, significantly detailed trade data can be used to further enhance our econometric results. It is to be noted that although the developing countries can enhance their economic growth through means of international trade, they might not be completely at par to maximize the full potential because of the absence of necessary technology, capital and various input factors.

Tariff remains the most important trade barrier, WTO has a main purpose to reduce this barrier by its member countries through mutual content. The basic effect of imposition of a tariff is the raise that occurs in the domestic prices of the goods of the country which is putting the import tariff. In case of developed economies, the rise in the price is less significant than the value of tariff due to the reason that the amount appears as reduced prices internationally. In case of developing economies, the domestic prices rise with the same ratio as the amount of tariff. This results in induction of a tariff gap between the trading countries, i.e. importing and exporting ones. Thus, there is a rise of production in the importing country, and a fall in the demand/consumption. This concepts well explains the protection function of the tariff. The trade of a country has a close relation to what its present stage of development is and the current level of industrialization. With time and economic advancements, the way in which the foreign trade is structured, and the policies suggested, undergoes alteration to comprehend the allocation of resources and the comparative advantage experienced.

The developed countries should support export from developing countries by the reduction of their own tariff barriers. The global trading system can undergo reforms to support the participation of the developing countries on international forums. It is observed that the developed countries have a less significant reduction of tariff over the years. As far as developing countries are concerned, a relationship is observed between tariff and economic growth but as mentioned earlier that it is not necessary that the country is well equipped to handle the eruption of economic growth due to trade liberalization, therefore policy makers cannot just use the tariff policy variable to 'liberalize' the trade assuming that in the long run the variables would be converging to equilibrium. Thus, along with the policy recommendation for the developing countries to liberalize the trade there is a need to adequately equip the economy with facilities such as education, political stability, infrastructure, if one wants to fully understand the potential of trade liberalization and playing with the policy variable of import tariff. Moreover, micro level studies may also be able to portray how can trade liberalization can be the most effective for the economic growth of any country

\section{REFERENCES}

Amelia U. Santos-Paulino, (2012). Trade, Income Distribution and Poverty in Developing Countries: A Survey, UNCTAD Discussion Papers 207, United Nations Conference on Trade and Development.

Alessandrini, M., Fattouh, B., Ferrarini, B., \& Scaramozzino, P. (2009). Tariff Liberalization and Trade Specialization in India. SSRN Electronic Journal. doi:10.2139/ssrn.1617144

Ballingall, John \& Giesecke, James \& Zuccollo, James. (2010). Tariffs in New Zealand: The economic impacts of retaining tariffs in New Zealand A dynamic CGE analysis. 
Cassing, J., McKeown, T. J., \& Ochs, J. (1986). The Political Economy of the Tariff Cycle. American Political Science Review, 80(3), 843-862. doi:10.2307/1960541

Jacobs, J. (2016). What' s the Big Deal? The Impact of TPP Tariff Removal on Canadian Trade.

Kassim, L. (2015). The Impact of Trade Liberalization on Export Growth and Import Growth in Sub-Saharan Africa. Regional Integration and Trade in Africa. doi:10.1057/9781137462053.0013

Kowalski, P. (2005). Impact of Changes in Tariffs on Developing Countries' Government Revenue. OECD Trade Policy Papers. doi:10.1787/210755276421

Lee, H.-L., Chang, C.-C., Weng, Y., Hsu, S.-M., Hsu, S.-H., \& Chen, Y.-C. (2014). An economy-wide analysis of impacts on Taiwan of reducing tariff escalation on agriculture-related products in WTO Doha Round negotiations. China Agricultural Economic Review, 6(1), 55-72. doi:10.1108/caer-06-2012-0058

Mkubwa, H., Mayasa, Mtengwa, B. A., \& Babiker, S. A. (2014). The Impact of Trade Liberalization on Economic Growth in Tanzania. International Journal of Academic Research in Business and Social Sciences, 4(5). doi:10.6007/ijarbss/v4-i5/879

Murphy, C. (2001). Modelling the Impact of Tariff Changes. Department of the Parliamentary Library, Research Paper, 269-296.

Nicita, A. (2009). The price effect of tariff liberalization: Measuring the impact on household welfare. Journal of Development Economics, 89(1), 19-27. doi:10.1016/j.jdeveco.2008.06.009

Pursell, G., \& Ahsan, F. M. Z. (2011). Sri Lanka's Trade Policies: Back to Protectionism. ASARC Working Paper 2011/03

Sachs, J. D., Warner, A., Aslund, A., \& Fischer, S. (1995). Economic Reform and the Process of Global Integration. Brookings Papers on Economic Activity, 1995(1), 1. doi: $10.2307 / 2534573$

Siddiqui, R., Siddiqui, R., \& Iqbal, Z. (1999). The Impact of Tariff Reforms on Income Distribution in Pakistan: A CGE-based Analysis. The Pakistan Development Review, 38(4II), 789-804. doi:10.30541/v38i4iipp.789-804

Sukiyono, K., \& Siriwardana, M. (2007). Short Run Impacts of Trade Liberalisation on the Regional Economy in Indonesia. Australasian Journal of Regional Studies, 13(1).

Sultan, P. (2008). Trade, Industry and Economic Growth in Bangladesh. Journal of Economic Cooperation, 4(29), 71-92.

Takeda, S., \& Ban, K. (2010). Regional Effects of Trade Liberalization in Japan: A CGE Analysis Based on an Interregional Input-Output Table. SSRN Electronic Journal. doi:10.2139/ssrn.1886019

Tarzi, S. M., \& Emami, A. (2014). Developed vs. Developing Countries and International Trade Liberalization: A Comparative Analysis, 1, 24-51.

Utkulu, U., \& Özdemir, D. (2004). Does Trade Liberalization Cause a Long Run Economic Growth in Turkey. Economic Change and Restructuring, 37(3-4), 245-266. doi:10.1007/s 10644-005-8080-8

Wacziarg, R. T., \& Horn Welch, K. (2003). Trade Liberalization and Growth: New Evidence. SSRN Electronic Journal. doi:10.2139/ssrn.471941

Zagha, R. \& Nankani, G. (2005). Economic growth in the 1990s: learning from a decade of reform. Choice Reviews Online, 43(04). doi:10.5860/choice.43-2318

\begin{tabular}{llll}
\hline JISR-MSSE & Volume 17 & Number 1 & January-June 2019 \\
\hline
\end{tabular}




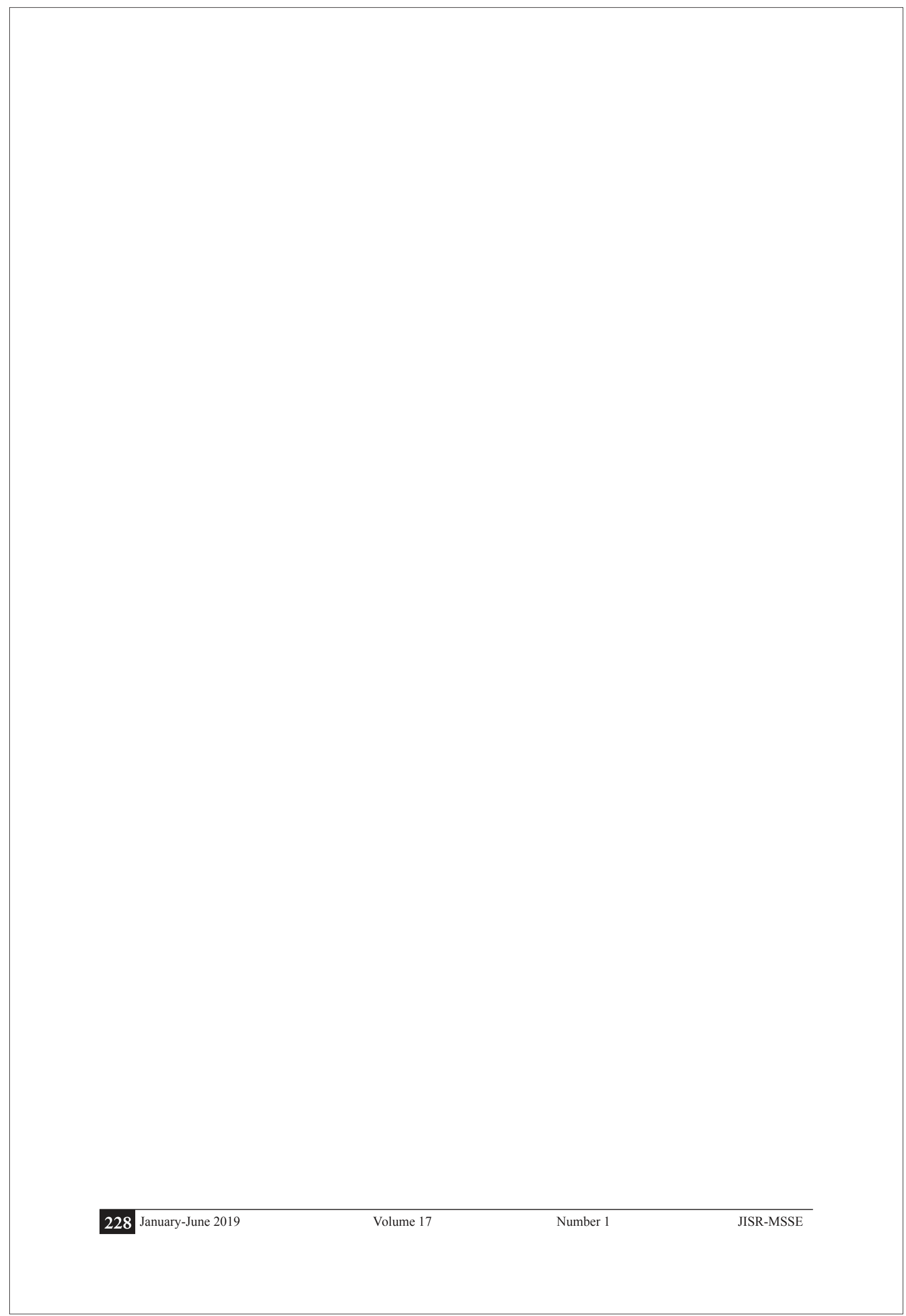

